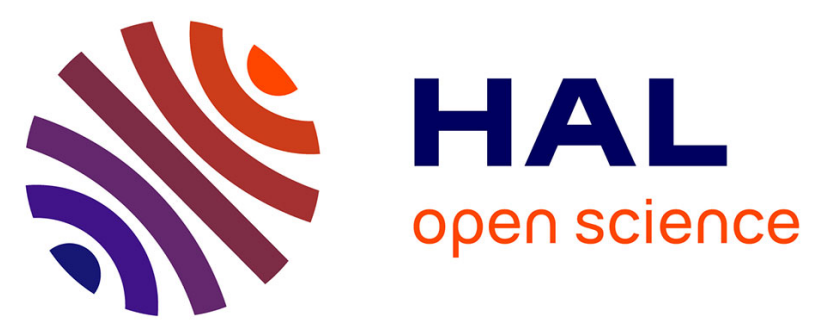

\title{
Artemisia arborescens Essential Oil Composition, Enantiomeric Distribution, and Antimicrobial Activity from Different Wild Populations from the Mediterranean Area
}

Mohammed El-Amin Said, Marcello Militello, Sergio Saia, Luca Settanni, Aurora Aleo, Caterina Mammina, Isabelle Bombarda, Pierre Vanloot, Christian Roussel, Nathalie Dupuy

\section{- To cite this version:}

Mohammed El-Amin Said, Marcello Militello, Sergio Saia, Luca Settanni, Aurora Aleo, et al.. Artemisia arborescens Essential Oil Composition, Enantiomeric Distribution, and Antimicrobial Activity from Different Wild Populations from the Mediterranean Area. Chemistry and Biodiversity, 2016, 13 (8), pp.1095 - 1102. 10.1002/cbdv.201500510 . hal-01442580

\author{
HAL Id: hal-01442580 \\ https://hal.science/hal-01442580
}

Submitted on 12 Apr 2018

HAL is a multi-disciplinary open access archive for the deposit and dissemination of scientific research documents, whether they are published or not. The documents may come from teaching and research institutions in France or abroad, or from public or private research centers.
L'archive ouverte pluridisciplinaire HAL, est destinée au dépôt et à la diffusion de documents scientifiques de niveau recherche, publiés ou non, émanant des établissements d'enseignement et de recherche français ou étrangers, des laboratoires publics ou privés. 


\title{
Artemisia arborescens Essential Oil Composition, Enantiomeric Distribution, and Antimicrobial Activity from Different Wild Populations from the Mediterranean Area
}

\author{
by Mohammed El-Amin Said ${ }^{\mathrm{a}}$ ), Marcello Militello*b ${ }^{\mathrm{b}}$ ), Sergio Saia ${ }^{\mathrm{c}}$ ), Luca Settanni ${ }^{\mathrm{b}}$ ), Aurora Aleo ${ }^{\mathrm{d}}$ ), Caterina Mammina $^{\mathrm{d}}$ ), \\ Isabelle Bombarda ${ }^{\mathrm{a}}$ ), Pierre Vanloot $^{\mathrm{a}}$ ), Christian Roussel ${ }^{\mathrm{e}}$ ), and Nathalie Dupuy ${ }^{\mathrm{a}}$ ) \\ a) EA4672 LISA Equipe METICA, Aix-Marseille Université, Case 451, Av. Escadrille Normandie Niémen, FR-13397 \\ Marseille Cedex 20 \\ b) Department of Agricultural and Forest Sciences (SAF), Università degli Studi di Palermo, Viale delle Scienze, Ed. 4, \\ IT-90128 Palermo (phone: +393294906241; fax: +390916515531; e-mail: marcellomilitello@tiscali.it) \\ c) Council for Agricultural Research and Economics (CREA) - Cereal Research Centre (CREA-CER), S.S. 673 km 25,200, \\ IT-71122 Foggia \\ d) Department of Health Promotion Sciences, "G. D’Alessandro", Università degli Studi di Palermo, Via del Vespro, \\ IT-90127 Palermo \\ e) Ecole Centrale, CNRS, iSm2 UMR 7313, Aix-Marseille Université, FR-13397 Marseille Cedex 20
}

\begin{abstract}
Aerial parts of Artemisia arborescens were collected from different sites of the Mediterranean area (southwestern Algeria and southern Italy) and the chemical composition of their essential oil (EO) extracted by hydrodistillation was studied by both gas chromatography (GC) equipped with an enantioselective capillary column and GC/mass spectrometry (GC/MS). The EOs obtained were tested against several Listeria monocytogenes strains. Using GC and GC/MS, 41 compounds were identified, accounting for $96.0-98.8 \%$ of the total EO. All EOs showed a similar terpene profile, which was rich in chamazulene, $\beta$-thujone, and camphor. However, the concentration of such compounds varied among the EOs. A. arborescens EO inhibited up to $83.3 \%$ of the L. monocytogenes strains, but the inhibitory spectrum varied among the EOs, with those from Algeria showing a higher inhibition degree than the Italian EOs. Such effect likely depended on the ketone ( $\beta$-thujone + camphor) content of the EO. The differences in the EO composition support the hypothesis that $A$. arborescens has at least two different chemotypes: a $\beta$-thujone and a chamazulene type. The EO inhibitory spectrum indicates the A. arborescens $\mathrm{EO}$ as a valuable option in the control of the food-borne pathogens.
\end{abstract}

Keywords: Enantiomeric distribution, Biological activity, Gram-negative bacteria, Volatile composition, Listeria monocytogenes.

\section{Introduction}

Artemisia arborescens L. is an aromatic and medicinal species belonging to the Asteraceae family [1][2]. It is widespread in the Mediterranean coast as an endemic species in many African and European countries [1] $[3-6]$. This species was used in the folk medicine for skin, bronchial catarrh, asthma, and insufficient bile production [7][8]. In addition, some of such effects were confirmed for antidiabetic; antipyretic; anti-inflammatory [1] [5][9]; antiangiogenic [10]; and antiviral activity against herpes simplex virus 1 and 2 [11]. From a biotechnological perspective, A. arborescens EO reduced the germination of some plant species belonging to distant taxa (Triticum, Brassica, Amaranthus) [12][13]. Similar effects were found when its methanolic and aqueous extracts were investigated for their allelopathic potential on Lactuca sativa seeds and plantlets [14]. This suggests that such an activity can also be played from some of its water-soluble compounds. A. arborescens EO slightly reduced the hatching of eggs and activity of juvenile of the nematode Meloidogyne javanica [15]. Similarly, A. arborescens $\mathrm{EO}$ showed a pesticidal (against Lymantria dispar, Aphis gossypii, Bemisia tabaci) [16] and an antifungal activities against several Candida albicans strains [17].

The effects of $A$. arborescens EO on some food-borne bacterial pathogens were also tested on few strains of Listeria monocytogenes and Escherichia coli [5][18] and the degree of inhibition varied among the strains. Such effects likely depended on the composition of the EO, since the EO of other Artemisia species strongly reduced M. javanica growth and such effect was mainly due to the concentration of the Artemisia ketone [15].

Indeed, the composition of $A$. arborescens EOs from different environments was found to be variable and various putative chemotypes were suggested. For example, in 
North America, A. arborescens EOs was characterized by chamazulene and camphor [19][20]. In the Mediterranean region, the chemical composition of the $\mathrm{EO}$ of $A$ arborescens from Morocco was characterized by $\beta$-thujone and camphor [21], that from north-west of Algeria (Tlemcen) only by camphor, whereas that from north-east of Algeria (Bejaia) by chamazulene and $\beta$-thujone [4][5]. The chemical composition of the essential oil of $A$. arborescens from Lebanon was characterized by $\beta$-thujone and chamazulene [1]. Those from the central Mediterranean islands Sicily and Sardinia showed some similarities with those from north-east of Algeria and north-west of Algeria, respectively [3][18][22 - 24].

Previous reports indicate that environmental factors can drive natural selection toward chemotypes more adapted to local environmental conditions [25 - 27].

However, little information is available about the antimicrobial effects of the EO of $A$. arborescens from different environments. Thus, the aim of this study was to characterize $A$. arborescens EOs from some contrasting environments in the Mediterranean basin in terms of both chemical composition and enantiomeric distribution of the main chiral compounds. In addition, the inhibitory effect against a wide collection of L. monocytogenes strains was screened.

\section{Results and Discussion}

\section{Climatic Index of the Collection Sites}

Strong differences were found among the collection sites in term of aridity, especially from October to April (late fall to early spring), as also displayed by the De Martonne index (Fig. 1). In particular, Bechar showed 12 dry months according to Bagnouls and Gaussen, Ain Sefra eight dry months (from April to November) and those from Italy showed only four dry months (from May to August).

\section{Essential Oil Composition}

The identification of the compounds was achieved by comparing their mass spectra with those of Wiley275 and NIST05a libraries as well as by comparing their retention indices with those of authentic samples [28]. Forty-one compounds were identified (Table 1), representing 96.0\%, $98.8 \%, 96.7 \%$, and $96.5 \%$ of the total composition of the samples from Bechar, Ain Sefra, Capo Zafferano, and Termini Imerese, respectively. EOs were mostly composed by oxygenated monoterpene (35.91-84.79\%) including $\alpha$-thujone $\quad(0.28-4.41 \%), \quad \beta$-thujone $(19.57-70.31 \%)$, camphor $(1.12-25.70 \%)$, and terpinen4-ol $(1.89-7.71 \%)$, followed by sesquiterpenes hydrocarbons $(8.44-49.42 \%) \quad$ including $\beta$-caryophyllene $(0.53-2.73 \%)$, germacrene D $(0.62-4.26 \%)$, chamazulene $(3.64-43.12 \%)$. Monoterpene hydrocarbons and oxygenated sesquiterpene were found in small fraction, lower than $12.74 \%$ and $1.85 \%$, respectively. These compounds included $\alpha$-pinene $(0.35-1.12 \%)$, camphene $(0.18-1.18 \%), \quad$ sabinene $(0.30-2.76 \%), \quad$ myrcene $(0.53-3.47 \%), \quad p$-cymene $(0.64-1.25 \%), \quad \gamma$-terpinene $(0.99-2.24 \%)$, elemol (lower than $0.62 \%)$, caryophyllene oxide (lower than $0.75 \%$ ), and $\beta$-eudesmol (lower than $1.22 \%)$.

\section{De Martonne index}

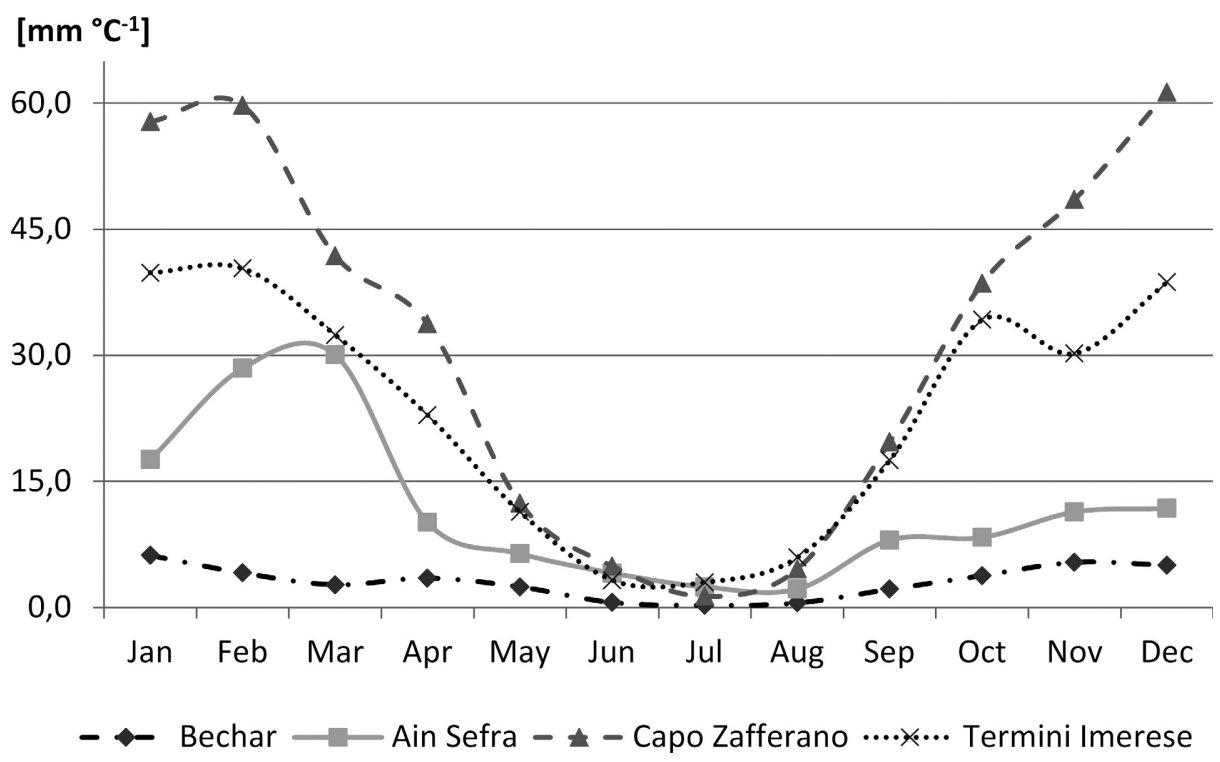

Fig. 1. De Martonne index, calculated on a monthly basis, of the collection sites from Algeria (Bechar and Ain Sefra) and Italy (Capo Zafferano and Termini Imerese). De Martonne index lower than 15, between 15 and 30, and higher than 30 indicate an arid month, semiarid to subhumid, and humid month, respectively. 
Table 1. Chemical composition by GC and GC/MS (expressed as \% of the total peak area) of the essential oil of Artemisia arborescens from two Algerian (Bechar and Ain Sefra) and two Italian (Capo Zafferano and Termini Imerese) sites

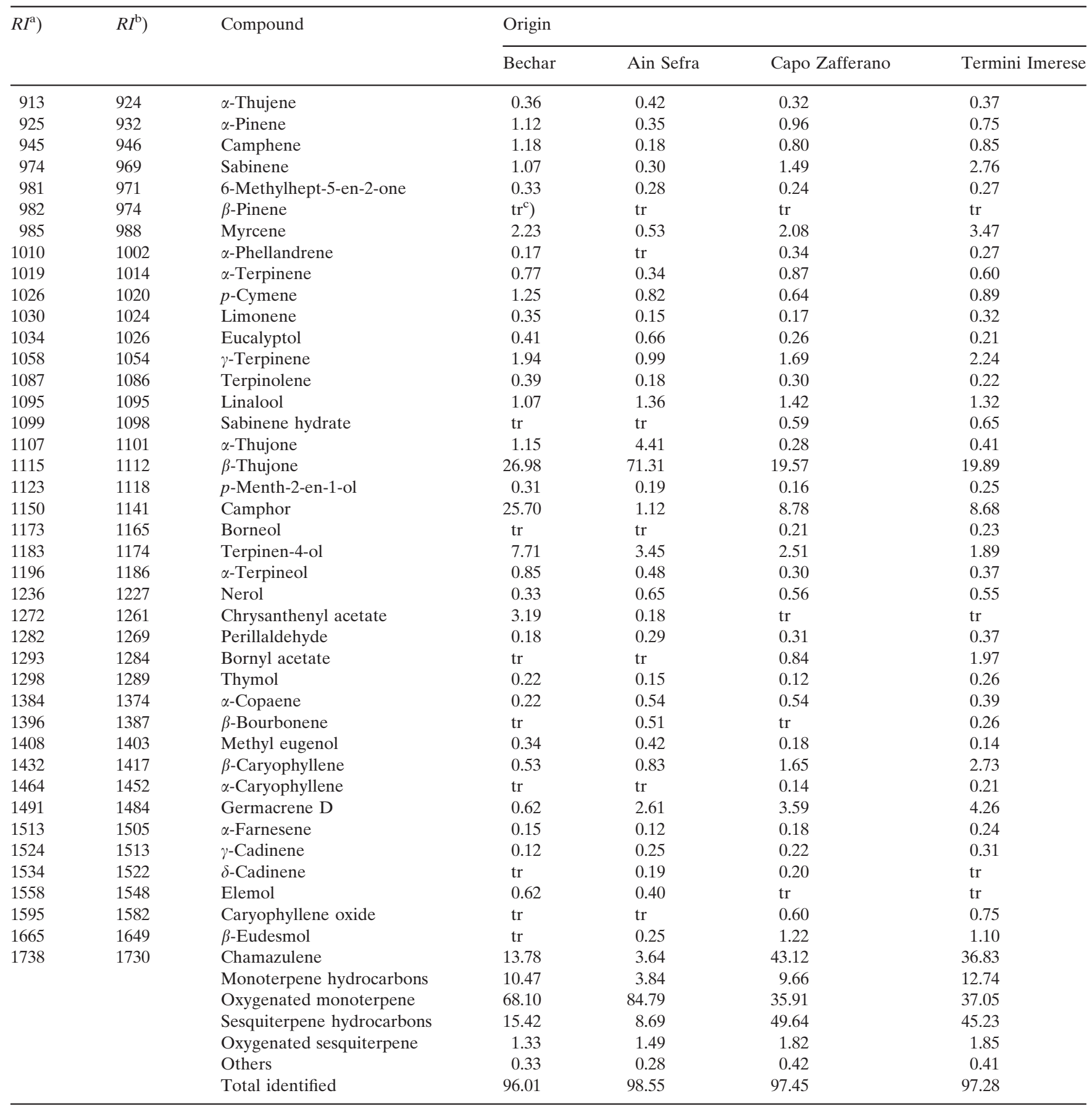

${ }^{\mathrm{a})} R I$, Retention indices on $H P-5$ capillary column. ${ }^{\mathrm{b}}$ ) $R I$, Retention indices in [50]. ${ }^{\mathrm{c}}$ ) tr, trace.

The EO from Ain Sefra was characterized by a high percentage of $\beta$-thujone $(71.31 \%)$, whereas that from Bechar by $\beta$-thujone (26.98\%), camphor $(25.70 \%)$, and chamazulene (13.78\%). The EOs from both Capo Zafferano and Termini Imerese were characterized by chamazulene $(36.83-43.12 \%), \quad \beta$-thujone $(19.57-19.89 \%)$, and camphor $(8.68-8.78 \%)$. This suggests that the accessions from Algeria (Ain Sefra and Bechar) could be designated as $\beta$-thujone and intermediate ( $\beta$-thujone + camphor) chemotypes, respectively, whereas those from southern Italy as chamazulene chemotype. These results agree with those reported from several authors [4][18][21][24][29] in which the EO of $A$. arborescens coming from collection sites nearby the sea showed similar $\beta$-thujone and chamazulene contents. The environmental conditions, especially drought, can strongly influence the composition 
Table 2. Enantiomeric distribution (\%) of $\alpha$-Thujone, $\beta$-Thujone, Camphor, and Terpinen-4-ol in the EOs

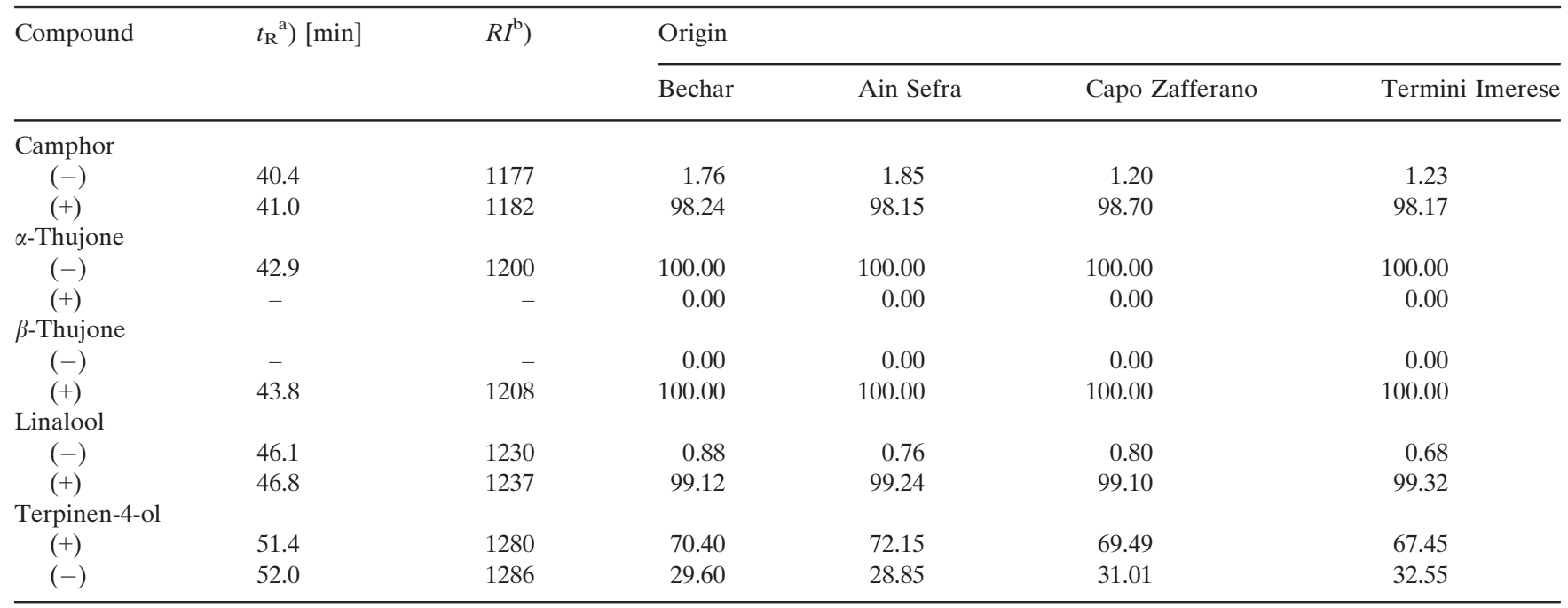

a) $t_{\mathrm{R}}$, Retention time. ${ }^{\mathrm{b}}$ ) $R I$, Retention indices on HP-5 capillary column Rt-bDEXse.

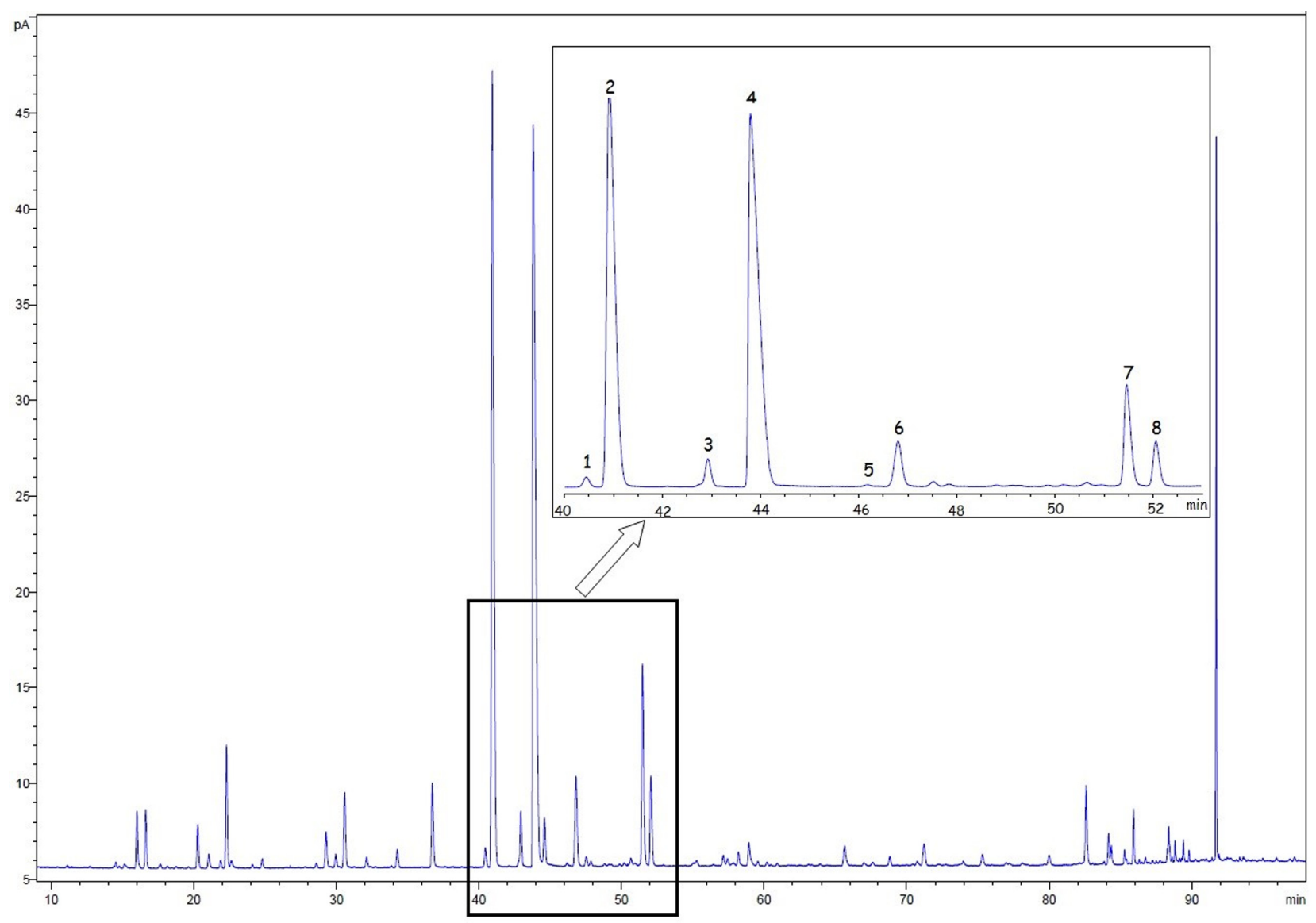

Fig. 2. Enantioseparation of the essential oil of A. arborescens by GC-FID on Rt-bDEXse capillary enantioselective column RESTEK $(30 \mathrm{~m} \times 0.25 \mathrm{~mm}$; film thickness $0.25 \mu \mathrm{m}) .1,(+)$-camphor; 2, (-)-camphor; 3, (-)-- $\alpha$-thujone; 4, (+)- $\beta$-thujone; 5, (-)-linalool; 6, (+)-linalool; 7 , $(+)$-terpinen-4-ol; 8, (-)-terpinen-4-ol.

of plant lipophilic fraction [30 - 33] due to their influence on the physiological mechanisms linked to the secondary metabolism [33 - 37]. In the present study, we found that sesquiterpenes were lower and monoterpenes higher in the EO coming from the relatively arid (Algeria) than the relatively humid (Italy) environments. Similar differences 
Table 3. Biocidal activity of essential oil of Artemisia arborescens from two Algerian (Bechar and Ain Sefra) and two Italian (Capo Zafferano and Termini Imerese) sites against 42 strains of Listeria monocytogenes

\begin{tabular}{|c|c|c|c|c|}
\hline Strain & Bechar & $\begin{array}{l}\text { Ain } \\
\text { Sefra }\end{array}$ & $\begin{array}{l}\text { Capo } \\
\text { Zafferano }\end{array}$ & $\begin{array}{l}\text { Termini } \\
\text { Imerese }\end{array}$ \\
\hline $13 \mathrm{BO}$ & $\left.+^{\mathrm{a}}\right)$ & + & + & $+1-$ \\
\hline $16 \mathrm{BO}$ & + & + & + & $+1-$ \\
\hline $8 \mathrm{BO}$ & + & + & + & - \\
\hline $3 \mathrm{BO}$ & + & + & + & + \\
\hline $2 \mathrm{BO}$ & ++ & ++ & + & ++ \\
\hline 135 & + & ++ & + & - \\
\hline 188 & + & + & + & + \\
\hline 132 & - & - & - & $+1-$ \\
\hline $14 \mathrm{BO}$ & - & - & - & - \\
\hline $12 \mathrm{BO}$ & - & - & - & $+1-$ \\
\hline 139 & ++ & + & $+/-$ & + \\
\hline $1 \mathrm{BO}$ & - & - & - & + \\
\hline $11 \mathrm{BO}$ & ++ & + & $+1-$ & $+1-$ \\
\hline 131 & + & + & + & - \\
\hline 138 & + & + & ++ & + \\
\hline 129 & - & - & - & + \\
\hline $23 \mathrm{BO}$ & ++ & ++ & + & + \\
\hline $21 \mathrm{BO}$ & + & + & $+/-$ & $+1-$ \\
\hline 19BO & + & ++ & + & N.A. $\left.{ }^{b}\right)$ \\
\hline $20 \mathrm{BO}$ & + & ++ & + & $+1-$ \\
\hline 185 & ++ & ++ & + & $+1-$ \\
\hline $1 \mathrm{BO}$ & + & + & $+1-$ & + \\
\hline 137 & + & + & + & + \\
\hline 186 & + & ++ & + & + \\
\hline 136 & + & + & $+1-$ & $+1-$ \\
\hline 182 & + & + & + & + \\
\hline 187 & ++ & + & + & + \\
\hline 184 & - & - & - & ++ \\
\hline 133 & ++ & ++ & $+1-$ & ++ \\
\hline 130 & + & + & + & + \\
\hline $4 \mathrm{BO}$ & ++ & ++ & + & $+1-$ \\
\hline $22 \mathrm{BO}$ & + & + & + & + \\
\hline $15 \mathrm{BO}$ & ++ & ++ & + & $+1-$ \\
\hline 179 & + & + & $+/-$ & $+1-$ \\
\hline 134 & + & + & $+/-$ & - \\
\hline $10 \mathrm{BO}$ & ++ & ++ & $+1-$ & $+1-$ \\
\hline $17 \mathrm{BO}$ & - & - & - & ++ \\
\hline $24 \mathrm{BO}$ & + & + & + & - \\
\hline $5 \mathrm{BO}$ & ++ & ++ & + & + \\
\hline $6 \mathrm{BO}$ & + & ++ & ++ & ++ \\
\hline $7 \mathrm{BO}$ & ++ & ++ & + & + \\
\hline 140 & + & ++ & $+1-$ & ++ \\
\hline Total & $\left.35(83.3 \%)^{\mathrm{c}}\right)$ & $35(83.3 \%)$ & $35(83.3 \%)$ & $35(83.3 \%)$ \\
\hline$+1-$ & $0(0.0 \%)$ & $0(0.0 \%)$ & $10(23.8 \%)$ & $13(30.9 \%)$ \\
\hline+ & $23(54.8 \%)$ & $20(47.6 \%)$ & $23(54.8 \%)$ & $16(38.1 \%)$ \\
\hline++ & $12(28.6 \%)$ & $15(35.7 \%)$ & $2(4.8 \%)$ & $6(14.3 \%)$ \\
\hline
\end{tabular}

a) Degree of inhibition: - no inhibition; +/- inhibition hint; + inhibition $(8-10 \mathrm{~mm})$; ++ hard inhibition $\left.(>10 \mathrm{~mm}) .{ }^{\mathrm{b}}\right)$ N.A., Not available. $\left.{ }^{c}\right)$ Percentage of the number of strains inhibited per each inhibition class.

were found in other plant species [38][39]. The accumulation of monoterpenes can be derived from an oxidation of the sequiterpene fraction and this can be the outcome of the plant response to the oxidative conditions, as also observed in other species [40-42].
The enantiomeric distribution of $\alpha$-thujone, $\beta$-thujone, camphor, linalool, and terpinen-4-ol in the EOs is reported in Table 2 and Fig. 2. We detected enantiomerically pure $(-)-\alpha$-thujone $(100 \%)$ and $(+)-\beta$-thujone $(100 \%)$ in all samples. Enantiomerically pure $(+)-\beta$-thujone was previously reported by El Montassir et al. [21] in the EO of A. arborescens from Morocco using enantioselective HPLC with polarimetric detection. Pure $(-)-\alpha$-thujone and (+)- $\beta$-thujone were also the main enantiomer in the oil of A. herba-alba [43] and Thuja occidentalis [44]. In $A$. arborescens EO, the enantiomers $(+)$ - $\alpha$-thujone and $(-)-\beta$-thujone were not found [29]. Enantiomerically almost pure (-)-camphor (between $98.15 \%$ and $98.77 \%$ ) and (+)-linalool (between $99.12 \%$ and $98.32 \%)$ were also found in the EO. (+)-Terpinen-4ol was found in amount exceeding 67\%. It has been showed that different enantiomers can be used to trace the fate of compounds in the plant/soil/atmosphere continuum [45], have different flavors [46], and activity on human health [47]. The results of the enantiomeric distribution of camphor, linalool, and terpinen-4-ol are similar with those previously reported for EO of $A$. arborescens from southern Italy [29], which showed that chiral compounds can differ in plants coming from different environments.

\section{Inhibitory Activity}

In this study, the antibacterial activity of $A$. arborescens EOs was tested against several L. monocytogenes strains. Previous investigations of EOs from this species growing wild in Sicily [18] indicated that L. monocytogenes is particularly sensitive to the EO, but the degree of inhibition can vary according to composition of the EO. Algerian EOs were more effective than Italian EOs both in terms of number of strains inhibited and for the extent of such an inhibition (Table 3). In particular, 35 strains were inhibited by the Algerian EOs, whereas less than 25 strains by the Italian EOs. Furthermore, a massive inhibition, measured as a diameter of the growth inhibition larger than $10 \mathrm{~mm}$, was displayed against 12 and 15 strains by the EO from Bechar and Ain Sefra, respectively. The EO from Termini Imerese showed a substantial inhibitory effect only against six strains, whereas a strong inhibition of L. monocytogenes by Capo Zafferano EO was found only against two strains.

The inhibitory activity of the EO against Gram-negative bacteria can depend upon several compounds and the interaction among single compounds. In our experiment, EOs from Algerian $A$. arborescens showed a higher ketone ( $\beta$-thujone + camphor) content, which also are the most abundant compounds in the EO, than the Italian EOs. Thus, it is likely that the ketones are responsible for the inhibitory activity of the EO, as also observed in another ketone-rich A. arborescens EO [18]. Nonetheless, such effect could also depend on other compounds including $\alpha$-pinene, 1,8-cineole, borneol, and thymol [48 - 50] or 


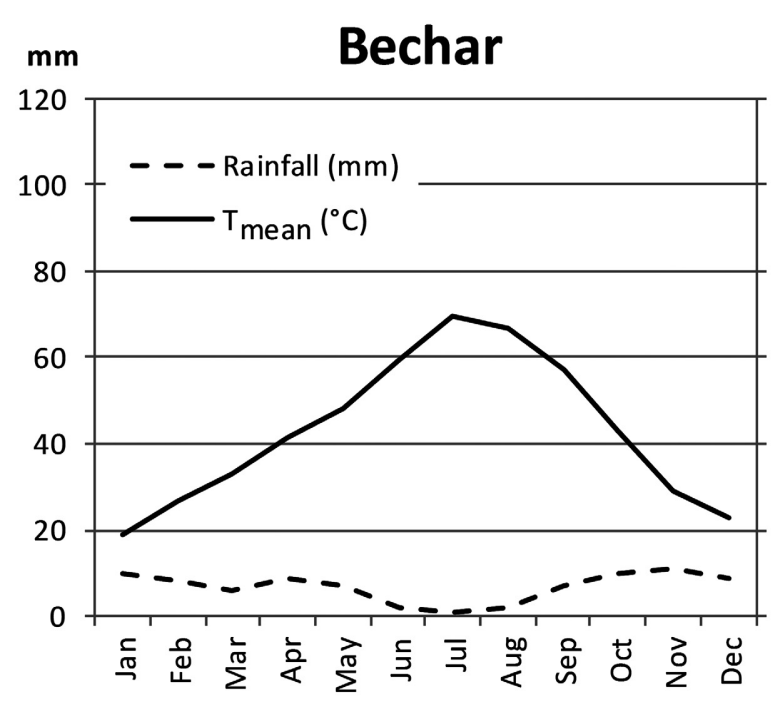

mm Capo Zafferano

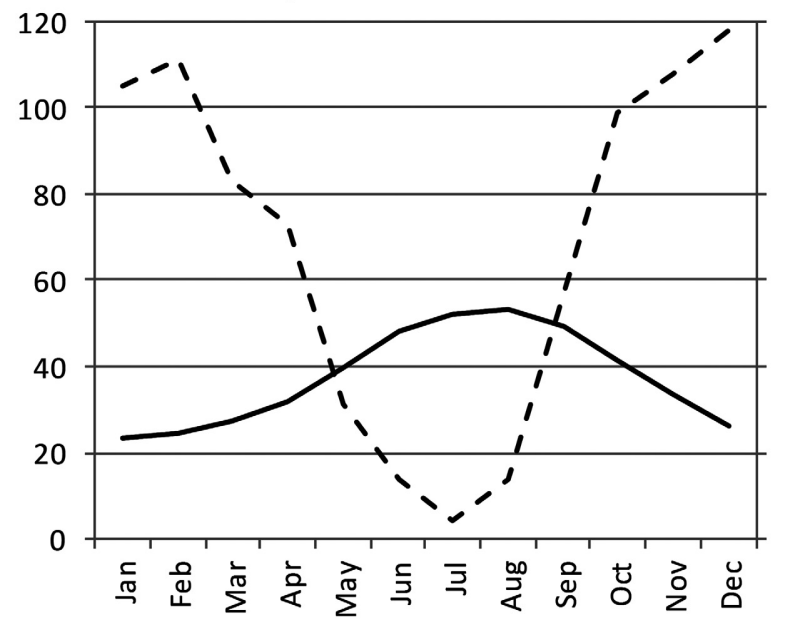

Ain Sefra

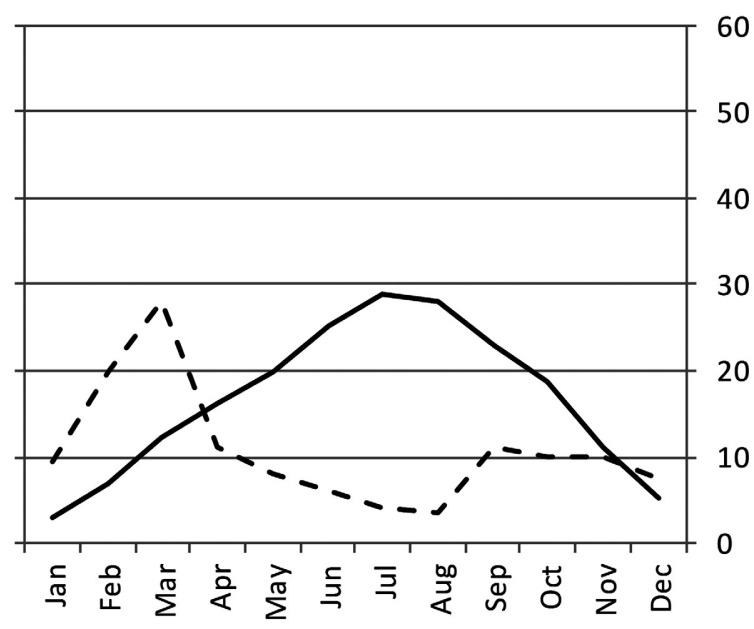

Termini Imerese

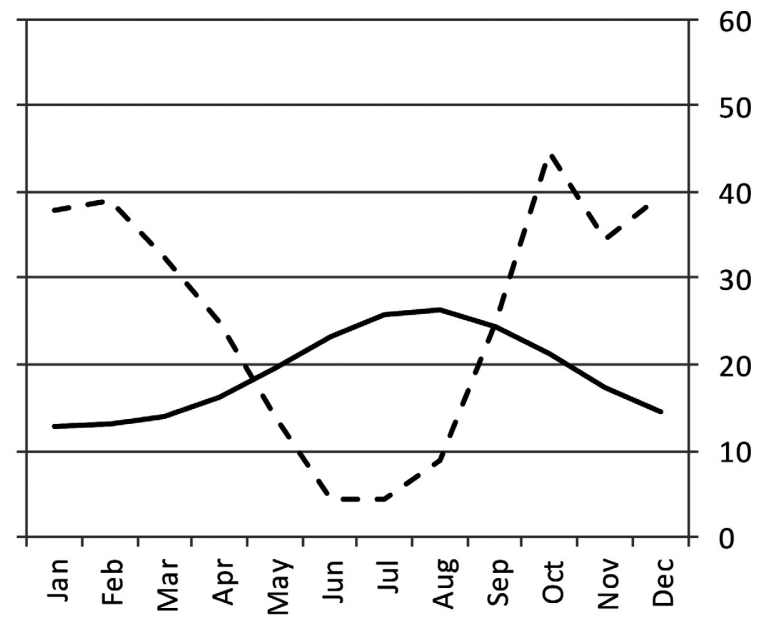

Fig. 3. Bagnouls-Gaussen diagrams of the average temperature $\left({ }^{\circ}, T_{\text {mean }}\right)$ and rainfall $(\mathrm{mm})$ of the collection sites from Algeria (Bechar and Ain Sefra) and Italy (Capo Zafferano and Termini Imerese).

the enantiomeric distribution of some compounds, as also found by Tabanca et al. [51], whereas few or no inhibitory activity could be attributed to chamazulene and germacrene D, which are likely active against fungi and Grampositive bacteria [18][52][53].

\section{Conclusions}

In conclusion, the results of this study showed that the EO of $A$. arborescens was characterized by a high inhibitory spectrum against $L$. monocytogenes. This implies that such EOs can be designated as a valuable option in the control of the food-borne pathogens. In addition, our results strongly support the hypothesis that $A$. arborescens has at least two different chemotypes: a $\beta$-thujone and a chamazulene type [19][22]. Further studies are needed to elucidate the role of the single compounds in the $A$. arborescens $\mathrm{EO}$ on the inhibition of bacteria.
We thank two anonymous reviewers for improving the manuscript.

\section{Experimental Part}

\section{Plant Material}

The above-ground biomass of plants from four natural populations of Artemisia arborescens was collected from western Algeria (Bechar and Ain Sefra) and southern Italy (Sicily: Capo Zafferano and Termini Imerese) during the blossom stage of each population. The coordinates of the collection sites are: Bechar 31 $54^{\prime} 59^{\prime \prime} \mathrm{N}$, $2^{\circ} 18^{\prime} 0^{\prime \prime} \mathrm{W}, 870 \mathrm{~m}$ above sea level (a.s.l.); Ain Sefra $32^{\circ} 37^{\prime} 33^{\prime} \mathrm{N}, 0^{\circ} 24^{\prime} 39^{\prime \prime} \mathrm{W}, 1238 \mathrm{~m}$ a.s.l; Capo Zafferano $38^{\circ} 6^{\prime} 48^{\prime \prime} \mathrm{N}, 13^{\circ} 31^{\prime} 14^{\prime \prime} \mathrm{E}, 10 \mathrm{~m}$ a.s.l.; and Termini Imerese $37^{\circ} 58^{\prime} 26^{\prime \prime} \mathrm{N}, 13^{\circ} 44^{\prime} 4^{\prime \prime} \mathrm{E}, 25 \mathrm{~m}$ a.s.l. The Bagnouls and 
Gaussen diagram of the collection sites are shown in Fig. 3.

\section{Essential Oil Extraction}

The biomass collected was subjected to hydrodistillation for $3 \mathrm{~h}$ using a Clevenger apparatus. The EO yields were $0.41,0.40,0.32,0.30(\% v / w)$ for sample from Bechar, Ain Sefra, Capo Zafferano, and Termini Imerese, resp. The EOs obtained were dried $\left(\mathrm{Na}_{2} \mathrm{SO}_{4}\right)$ and stored in a sealed vial in the dark at $4^{\circ}$ before analysis.

\section{GC/MS Analysis}

GC/MS analyses were performed on a $7890 A$ GC system coupled to a 5975C VL mass spectrometer detector (Agilent Technologies) equipped with a HP-5MS capillary column $(J \& W$ Scientific, $30 \mathrm{~m} \times 0.25 \mathrm{~mm} \times 0.25 \mu \mathrm{m})$. Data acquisition and processing were performed using the MSD Chemstation E.01.01.335 (Agilent) software [21] [44]. A quantity of $1 \mu \mathrm{l}$ of diluted EO $(0.05 \mathrm{~g}$ in $1.5 \mathrm{ml}$ of $\mathrm{CH}_{2} \mathrm{Cl}_{2}$ ) was injected. The experimental conditions developed in the laboratory were solvent delay, 2 min; column temp. program, $2 \mathrm{~min}$ at $80{ }^{\circ} \mathrm{C}$, then $80{ }^{\circ} \mathrm{C}$ to $200{ }^{\circ} \mathrm{C}\left(5^{\circ} \mathrm{C} / \mathrm{min}\right)$, then $200{ }^{\circ} \mathrm{C}$ to $260{ }^{\circ} \mathrm{C}\left(20{ }^{\circ} \mathrm{C} / \mathrm{min}\right)$, and held at final temp. for $5 \mathrm{~min}$; temps. of injector (split ratio 1:60) and detector were $250{ }^{\circ} \mathrm{C}$; carrier gas was $\mathrm{He}$ at a flow rate of $1.2 \mathrm{ml} / \mathrm{min}$; ionization voltage $70 \mathrm{eV}$; electron multiplier, $1 \mathrm{kV}$.

\section{GC Analysis}

GC Analyses were performed on a 7890A GC (Agilent Technologies) system with a flame-ionization detector (FID) equipped with a HP5 capillary column (J\&W Scientific, $30 \mathrm{~m} \times 0.25 \mathrm{~mm} \times 0.25 \mu \mathrm{m})$ and Rt-bDEXse enantioselective capillary column (Restek, $30 \mathrm{~m} \times 0.25$ $\mathrm{mm} \times 0.25 \mu \mathrm{m})$. Data acquisition and processing were performed using the Chemstation B.04.03-SP1 (87) (Agilent) software. Experimental conditions for $\mathrm{HP} 5$ were: oven temp. $2 \mathrm{~min}$ at $80{ }^{\circ} \mathrm{C}$, then $80{ }^{\circ} \mathrm{C}$ to $200{ }^{\circ} \mathrm{C}\left(5^{\circ} \mathrm{C} /\right.$ min), then $200{ }^{\circ} \mathrm{C}$ to $260{ }^{\circ} \mathrm{C}\left(20{ }^{\circ} \mathrm{C} / \mathrm{min}\right)$, and held at final temp. for $5 \mathrm{~min}$. Injector and detector temps. were set at $250{ }^{\circ} \mathrm{C}$. Experimental conditions for Rt-bDEXse were: oven temp. $1 \mathrm{~min}$ at $40{ }^{\circ} \mathrm{C}$, then $40{ }^{\circ} \mathrm{C}$ to $120{ }^{\circ} \mathrm{C}$ $\left(1{ }^{\circ} \mathrm{C} / \mathrm{min}\right)$, then $120{ }^{\circ} \mathrm{C}$ to $200{ }^{\circ} \mathrm{C}\left(5^{\circ} \mathrm{C} / \mathrm{min}\right)$, and held at final temp. for $5 \mathrm{~min}$. Injector and detector temps. were set at $230^{\circ}$.

$\mathrm{H}_{2}$ was the carrier gas at a flow rate of $1.2 \mathrm{ml} / \mathrm{min}$. Linear retention indices were calculated with reference to $n$-alkanes $\left(\mathrm{C}_{8}-\mathrm{C}_{28}\right)$. EOs compositions were given as relative area percentages and for peak accounting for more than $0.1 \%$ of the total peak's area. The identification of the compounds was based on the comparison of their retention indices with those of authentic samples [28].

\section{Antimicrobial Activity}

The inhibitory properties of $A$. arborescens EOs on bacterial growth was tested against 42 L. monocytogenes strains. All strains were retrieved from the culture collection of the Department of Sciences for Health Promotion and Mother-Child Care "G. D'Alessandro" (Palermo, Italy). All strains were isolated from foodstuff or human stools, subcultured in brain-heart infusion (BHI) agar (Oxoid) and incubated overnight at $37^{\circ}$.

The antibacterial activities were tested applying the paper disc diffusion method reported by Militello et al. [18]. The indicator strains were inoculated at a final concentration of $10^{7} \mathrm{CFU} / \mathrm{ml}$ in soft agar $(0.7 \mathrm{~g} / \mathrm{l})$. Sterile water and streptomycin $(10 \%, w / v)$ were used as negative and positive controls, resp. Plates were incubated at $37^{\circ}$ for $24 \mathrm{~h}$ and the inhibitory activity was evaluated as positive if a definite clear area was detected around the paper disc.

\section{REFERENCES}

[1] M. El Beyrouthy, M. Labaki, F. Cazier, S. Najm, A. AbouKaïs, Leban. Sci. J. 2011, 13, 71.

[2] J. Valles, E. D. Mc Arthur, in 'Shrubland Ecosystem Genetics and Biodiversity: proceedings', Ed. E. D. McArthur, D. J. Fairbanks, Proc. RMRS-P-21, USDA Forest Service, Rocky Mountain Research Station Ogden, UT, 2000, p. 67.

[3] F. Lai, S. A. Wissing, R. H. Müller, A. M. Fadda, AAPS Pharm. Sci. Tech. 2006, 7, 10.

[4] A. Abderrahim, K. Belhamel, J.-C. Chalchat, G. Figuérédo, Rec. Nat. Prod. 2010, 4, 87.

[5] K. Younes, S. Merghache, N. Djabou, D. Merghache, A. Muselli, B. Tabti, J. Costa, Afr. J. Pharm. Pharmacol. 2012, 6, 2912.

[6] P. Quézel, S. Santa, Nouvelle Flore de l'Algérie et des Régions Désertiques Méridionale, Éditions du Centre national de la Recherche scientifique, Paris, 1962.

[7] J. Rose, S. Earle, The World of Aromatherapy, Berkeley, California, 1996.

[8] A. Carrubba, R. Scalenghe, J. Sci. Food Agric. 2012, 92, 1150

[9] M. J. Abad, L. M. Bedoya, L. Apaza, P. Bermejo, Molecules 2012, 17, 2542.

[10] R. Costa, S. Ragusa, M. Russo, G. Certo, F. A. Franchina, A. Zanotto, E. Grasso, L. Mondello, M. P. Germanò, J. Pharm. Biomed. Anal. 2016, 117, 499.

[11] M. Saddi, A. Sanna, F. Cottiglia, L. Chisu, L. Casu, L. Bonsignore, A. De Logu, Ann. Clin. Microbiol. Antimicrob. 2007, 6, 10.

[12] M. Militello, A. Carrubba, in 'Natural Products: Research Reviews', Ed. V. K. Gupta, Daya Publishing House, New Delhi, 2016, p. 389.

[13] N. Dudai, A. Poljakoff-Mayber, A. M. Mayer, E. Putievsky, H. R. Lerner, J. Chem. Ecol. 1999, 25, 1079.

[14] F. Araniti, A. Lupini, A. Sorgonà, F. Conforti, M. Marrelli, G. A. Statti, F. Menichini, M. R. Abenavoli, Nat. Prod. Res. 2013, 27, 880 .

[15] Y. Oka, S. Nacar, E. Putievsky, U. Ravid, Z. Yaniv, Y. Spiegel, Phytopathology 2000, 90, 710.

[16] F. Lai, G. Loy, M. Manconi, M. L. Manca, A. M. Fadda, AAPS Pharm. Sci. Tech. 2007, 8, 67.

[17] S. B. Erel, G. Reznicek, S. G. Şenol, N. U. K. Yavaşoğulu, S. Konyalioğlu, A. U. Zeybek, Turk. J. Biol. 2012, 36, 75. 
[18] M. Militello, L. Settanni, A. Aleo, C. Mammina, G. Moschetti, G. M. Giammanco, M. A. Blàzquez, A. Carrubba, Curr. Microbiol. 2011, 1274.

[19] R. Pappas, S. Sheppard-Hanger, Aromather. J. 2000, 10, 30.

[20] A. O. Tucker, M. J. Maciarello, G. Sturtz, J. Essent. Oil Res. 1993, 5, 239.

[21] D. El Montassir, A. Aamouche, N. Vanthuyne, M. Jean, P. Vanloot, M. Taourirte, N. Dupuy, C. Roussel, J. Sep. Sci. 2013, $36,832$.

[22] M. Militello, A. Carrubba, M. A. Blázquez, J. Essent. Oil Res. 2012, 24, 229.

[23] T. Sacco, C. Frattini, C. Bicchi, Planta Med. 1983, 47, 49.

[24] L. Ornano, A. Venditti, M. Ballero, C. Sanna, L. Quassinti, M. Bramucci, G. Lupidi, F. Papa, S. Vittori, F. Maggi, A. Bianco, Chem. Biodiversity 2013, 10, 1464.

[25] A. Angioni, A. Barra, E. Cereti, D. Barile, J. D. Coïsson, M. Arlorio, S. Dessi, V. Coroneo, P. Cabras, J. Agric. Food Chem. 2004, 52, 3530.

[26] H. de Kroon, H. Huber, J. F. Stuefer, J. M. van Groenendael, New Phytol. 2005, 166, 73.

[27] A. Hajdari, B. Mustafa, D. Nebija, E. Miftari, C. L. Quave, J. Novak, Chem. Biodiversity 2015, 12, 1706.

[28] R. P. Adams, Identification of Essential Oil Components by Gas Chromatography/Mass Spectrometry, Allured Publishing Corporation, Carol Stream, IL, 2007.

[29] M. Lo Presti, M. L. Crupi, B. d'A. Zellner, G. Dugo, L. Mondello, P. Dugo, S. Ragusa, J. Essent. Oil Res. 2007, 19, 218.

[30] F. Martinelli, D. Remorini, S. Saia, R. Massai, P. Tonutti, Sci. Hortic. 2013, 159, 52.

[31] A. Giovino, F. Martinelli, S. Saia, J. Integr. Plant Biol. 2015, in press.

[32] S. Saia, P. Ruisi, V. Fileccia, G. Di Miceli, G. Amato, F. Martinelli, PLOS ONE 10, e0129591.

[33] N. Abdelmajeed, E. Danial, H. Ayad, Arch. Des. Sci. 2013, 66, 100.

[34] H.-B. Shao, L.-Y. Chu, C. A. Jaleel, C.-X. Zhao, C. R. Biol. 2008, 331, 215.

[35] N. S. Sangwan, A. H. A. Farooqi, F. Shabih, R. S. Sangwan, Plant Growth Regul. 2001, 34, 3.

[36] R. Farhoudi, D.-J. Lee, M. Hussain, J. Essent. Oil Bear. Plants 2014, 17, 26.

[37] Z. F. Baher, M. Mirza, M. Ghorbanli, M. B. Rezaii, Flavour Fragrance J. 2002, 17, 275.
[38] T. Tuttolomondo, S. La Bella, M. Licata, G. Virga, C. Leto, A. Saija, D. Trombetta, A. Tomaino, A. Speciale, E. M. Napoli, L. Siracusa, A. Pasquale, G. Curcuruto, G. Ruberto, Chem. Biodiversity 2013, 10, 411.

[39] E. M. Napoli, L. Siracusa, A. Saija, A. Speciale, D. Trombetta, T. Tuttolomondo, S. La Bella, M. Licata, G. Virga, R. Leone, C. Leto, L. Rubino, G. Ruberto, Chem. Biodiversity 2015, 12, 1075.

[40] H. Rennenberg, F. Loreto, A. Polle, F. Brilli, S. Fares, R. S. Beniwal, A. Gessler, Plant Biol. 2006, 8, 556.

[41] C. E. Vickers, J. Gershenzon, M. T. Lerdau, F. Loreto, Nat. Chem. Biol. 2009, 5, 283.

[42] F. Brilli, C. Barta, A. Fortunati, M. Lerdau, F. Loreto, M. Centritto, New Phytol. 2007, 175, 244.

[43] M. E.-A. Said, P. Vanloot, I. Bombarda, J.-V. Naubron, E. M. Dahmane, A. Aamouche, M. Jean, N. Vanthuyne, N. Dupuy, C. Roussel, Anal. Chim. Acta 2016, 903, 121.

[44] R. Gniłka, A. Szumny, A. Białońska, C. Wawrzeńczyk, Phytochem. Lett. 2012, 5, 340.

[45] W. J. Hegeman, R. W. Laane, Rev. Environ. Contam. Toxicol. 2002, 173, 85.

[46] K. Bauer, D. Garbe, H. Surburg, 'Common Fragrance and Flavor Materials', VCH, Weinheim, 1997, pp. 49, 60

[47] B. Waldeck, Chirality 1993, 5, 350.

[48] N. Chaftar, M. Girardot, N. Quellard, J. Labanowski, T. Ghrairi, K. Hani, J. Frère, C. Imbert, Chem. Biodiversity 2015, 12, 1565.

[49] B. Çetin, H. Özer, A. Çakir, E. Mete, M. Tosun, E. Öztürk, T. Polat, A. Kandemir, Chem. Biodiversity 2009, 6, 2302.

[50] I. C. Marinas, E. Oprea, M. C. Chifiriuc, I. A. Badea, M. Buleandra, V. Lazar, Chem. Biodiversity 2015, 12, 1554.

[51] N. Tabanca, N. Kirimer, B. Demirci, F. Demirci, K. H. C. Baser, J. Agric. Food Chem. 2001, 49, 4300.

[52] M. Gaviria, C. Quijano, J. Pino, S. Madrinán, Chem. Biodiversity 2011, 8, 532 .

[53] D. Kalemba, A. Kunicka, Curr. Med. Chem. 2003, 10, 813. 